\title{
To what extent residual alveolar ridge can be preserved by implant? A systematic review
}

\author{
Ahmed Khalifa Khalifa ${ }^{1,2}$, Masahiro Wada ${ }^{2 *}$, Kazunori lkebe ${ }^{2}$ and Yoshinobu Maeda ${ }^{2}$
}

\begin{abstract}
Background: It has been reported that the load for (or to) implant-supported restoration may lead to bone remodeling as bone resorption and/or formation. While many authors supported the process of bone resorption, others elaborated bone apposition and increasing bone density close and remote to implant body (or fixture). This may suggest the role of the implant to reserve alveolar ridge from physiologic/pathologic resorption. The aim of this systematic review was to predict to how extend dental implants can preserve the residual alveolar ridge based on previous clinical investigations.
\end{abstract}

Methods: This systematic review based on the retrospective and prospective studies, randomized clinical trial, and case reports. The process of searching for proposed articles included PubMed, Ovid, and Web of Science databases, with specific inclusion and exclusion criterion.

Results: A total 2139 citations were identified. After expunging the repeated articles between databases and application of exclusion and inclusion criteria, 18 articles were found to meet the topic of this systematic review. Many of the articles reported bone preservation with implant-assisted restorations, and the rest denoted noticeable bone apposition.

Conclusion: According to the published clinical studies, the behavior of bone remodeling around implant predicts a sort of residual alveolar bone preservation.

Keywords: Dental implants, Ridge preserving, Alveolar bone remodeling

\section{Review}

Introduction

Edentulism is rated between 7 and 69\% internationally [1]. Many biological and non-bilogical predisposing factors lead to the main result of edentulism [2]. Regardless the debate to understand the way of resorption [3], the loss of periodontal ligament by tooth extraction leaves alveolar bone without a chance of reformation which leads to bone resorption only. The resorption shows variation in rate with recorded fast bone loss at the first 6 months after extraction and the following 2 years [4].

As pernicious sequelae of edentulism, the patient lacks most of the ordinary oral function which requires planned

\footnotetext{
*Correspondence: masahiro@dent.osaka-u.ac.jp

2Department of Prosthodontics, Gerodontology and Oral Rehabilitation,

Osaka University Graduate School of Dentistry, 1-8 YamadaokaSuita, Osaka

565-0871, Japan

Full list of author information is available at the end of the article
}

rehabilitation. Implant therapy is one of the recent trends to restore oral functions [5-7]. Besides the rehabilitation purposes, implants show other favorable biological effects on the bone state. Many authors [8-10] revealed the ability of the implant to regain bone density at healing and adapt to the applied load. As an evitable fate, residual alveolar ridge shows resorption under the conventional complete denture. This varies according to prosthetic planning, construction, and maintenance, as well as systemic predisposing factors [11-13]. Although the presence of implant beneath complete or partial denture improves denture foundation and augments patient satisfaction [7, 14], there is a controversy about the role of implant overdenture in the process of ridge reshaping after loading.

The tracing of the bone resorption is difficult for the complete denture with the continuous rated atrophy of the residual alveolar ridge beneath the conventional 
denture $[15,16]$. Rather than monitoring the bone atrophy, this review investigates the capability of the implant to be responsible for preserving residual alveolar ridge bone and the role of implant-assisted restoration to reduce the alveolar ridge atrophy.

\section{Methods}

\section{Focus question}

The (PIO) question to be focused was "In patient with implant restoration, what is the chance of residual alveolar ridge preserving and bone formation in the adaptive remodeling and what are the features of this preservation?"

\section{Search strategy}

The required documents were collected from PubMed, Web of Science, and Ovid databases. For expanding the traces of researching, further readings for the bibliography of the relevant publications and hand searching for some denoted articles were done. The keywords, for intervention and outcome, used in research engines in databases as "implant overdenture," "implant bone resorption," "alveolar ridge preservation," "improve alveolar ridge," "implant bone remodeling," "implant bone reformation," and "implant bone growth" (Table 1). In all databases, the filters of human, English article, and dental journals were applied.

\section{Inclusion and exclusion criteria of studies}

Inclusion criteria for the selected publications included the full-text articles written in English. Case reports also were included. Articles reported bone preservation or bone apposition even in clinical notifications or in the context were included. Studies that revealed improving bone density around implant were involved. The exclusion criteria included papers with only abstract available, while articles that deal only with discussing resorption through the remodeling process around cervical and/or implant body were excluded. Any articles related to abnormal conditions as maxillofacial patients, or treatments of systematic diseased patients, were not considered. Articles related to the effect of the implant on the bone for the opposing arch were excluded. Selection of articles is based on the title and the abstract reading. Some articles were excluded after full reading because of the absence of interest. Other articles were added from the existed citation bibliography (Table 1 ).

\section{Data extraction and assessment}

From the final included articles $(n=18)$, the following characteristics were tabulated:

\section{Author and the year of publishing}

Number of patients and implants mounted

Average age of patients (exact age in case reports)

Area of implant placement

Type of prosthetic restoration

Follow-up period

Bony changes and declarations of the quality and quantity of remodeling (if present)

Study design

\section{Results}

Initial search retrieved a total 2139 citations. After discarding the repeated articles among databases, revising of titles extruded 668 articles as out of interest for this review. The remaining articles are disclosed more by abstract. We excluded 434 citations due to concentration on bone remodeling with an abnormal situation like compromised patients or with localized problems as maxillofacial patients or not focus on the process of ridge progression under different restorations. The rest of the articles were read carefully to extract conclusions or notices related to positive bone remodeling, bone preserving, bone formation, or increasing bone density of the alveolar ridge with implant. Articles which could not be retrieved as the reference numbers 21 and 22 in the article of Davis et al. [17] were not included. Other articles [18-21] $(n=4)$ were added manually after reading the bibliography of previous citations. The final articles $(n=18)$ were selected according to the previous exclusion and inclusion criteria (Fig. 1). All citations $(n=18)$ share the point of bone preservation with implant restoration or enhancement of bone density or, at least, reduction of alveolar bone resorption rate after implant placement (Table 2).

Table 1 Systematic search strategy

\begin{tabular}{|c|c|}
\hline Focus question & $\begin{array}{l}\text { In patient with implant restoration, what is the chance of residual alveolar ridge preserving and bone } \\
\text { formation in the adaptive remodeling and what are the features of this preservation? }\end{array}$ \\
\hline \multicolumn{2}{|l|}{ Search strategy } \\
\hline Population & $\# 1$-edentulous patient \\
\hline Intervention & \#2_-implant OR overdenture OR fixed bridge OR transmandibular implant OR full rehabilitation \\
\hline Outcome & $\begin{array}{l}\text { \#3-bone density OR volume change OR bone formation OR bone apposition OR bone deposition } \\
\text { OR bone preserving OR bone preservation OR bone maintain OR bone increase }\end{array}$ \\
\hline Search combination & $\# 1$ AND (\#2 OR \#3) \\
\hline
\end{tabular}




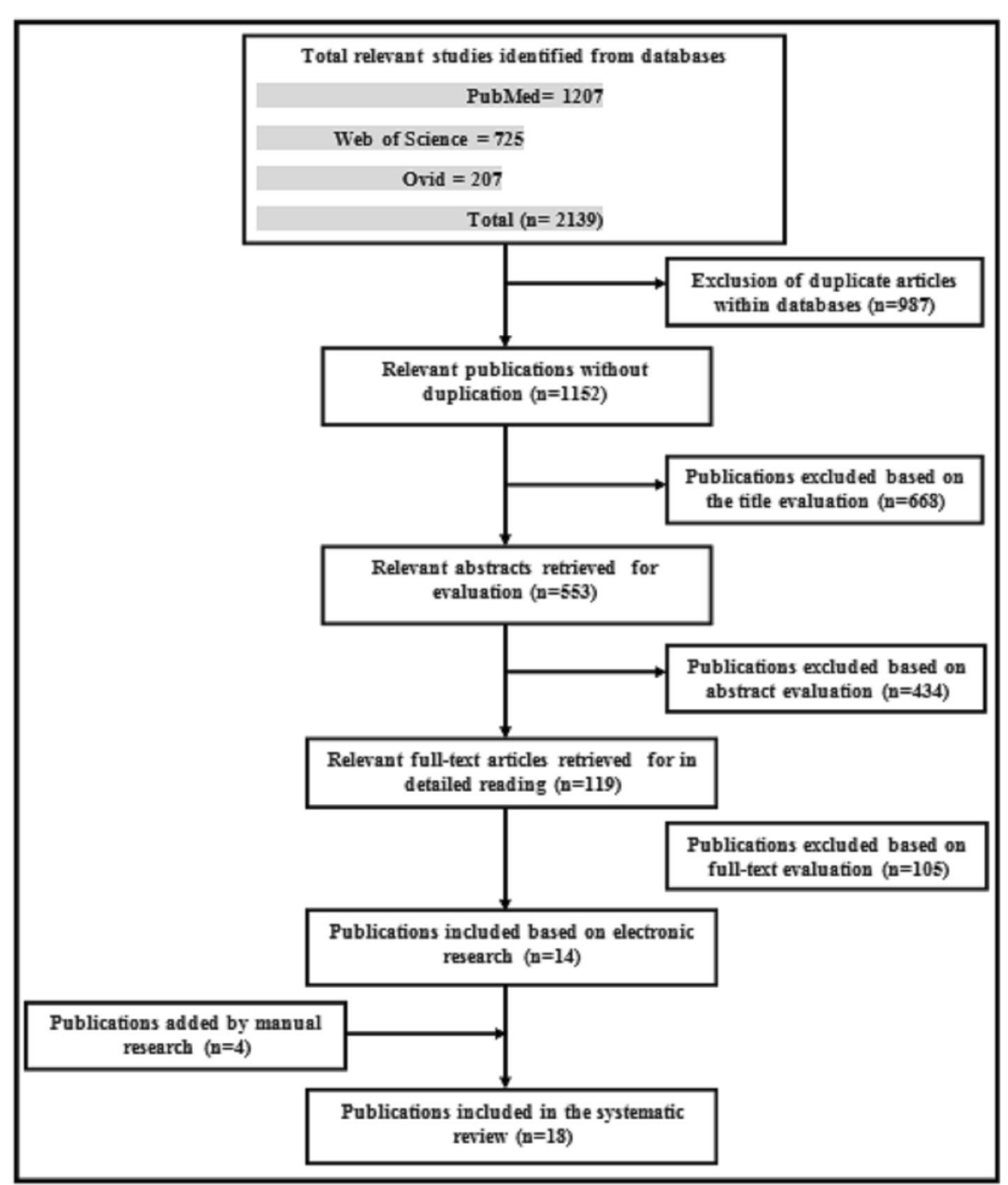

Fig. 1 The final articles $(n=18)$ were selected according to the previous exclusion and inclusion criteria

\section{Discussion}

\section{Implant role to enhance bone density}

Apparently, there is an enduring adaptive process surrounding the implant which sustains the rigid interface between alveolar bone and implant after non-destructive surgical and loading procedures. Like other body bones, and according to Wolff's law, bone has the ability to differentiate with different stresses applied [22]. This reform is started from the time of surgical conduction of implant and continued to support the implant to withstand the uploading forces [8, 9, 23-25]. Greater bone modification may occur at the alveolar bone around implants in partially edentulous patients [26, 27]. Roberts et al. [28] described the situation and the process as the ankylosed tooth which acts without bracing the attachment to bone and carries a heavy load. The adaptive modeling of endosseous implants, as a response to load, is a massive build-up of immature buttress-like skeleton which then decrease externally as the interior layers become more mature [28].

Like ankylosed tooth, implant-supported fixed prosthetic treatment might have a preservative effect on residual alveolar bone [29]. A radiographic-based quantitative study carried by Ichikawa et al. [30] displayed an improvement of bone density and bone formation related to load applied after a short period of implant service. With transmandibular implant, bone maintaining [18] or even formation and the highest increase in the bone were recorded [31]. The study for 146 patients with severely resorbed ridge treated with transmandibular implant denoted bone formation with all cases during follow-up period extended 51 months [32]. Within 9-year follow-up for 81 patients, Dhima et al. [33] denoted about $0.94 \mathrm{~mm}$ growth of bone. In a different study, periimplant bone density grew around implants after 5 years 
Table 2 Clinical studies included

\begin{tabular}{|c|c|c|c|c|c|c|c|c|c|}
\hline \multirow[b]{2}{*}{ Reference } & \multicolumn{2}{|c|}{ Patients } & \multicolumn{3}{|c|}{ Intervention } & \multirow[t]{2}{*}{ Follow-up } & \multicolumn{2}{|l|}{ Outcome } & \multirow[t]{2}{*}{ Study } \\
\hline & No. & $\mathrm{Age}^{\mathrm{a}}$ & $\begin{array}{l}\text { No. of } \\
\text { implants }\end{array}$ & Position & $\begin{array}{l}\text { Supra- } \\
\text { structure }\end{array}$ & & Change & Declarations & \\
\hline $\begin{array}{l}\text { (DAVIS et al. } \\
\text { 1999) [17] }\end{array}$ & 44 & 61.2 & NG & Symphyseal & Fixed & $6.6 Y^{a}$ & $\begin{array}{l}\text { VBH } \\
(-.8 \text { to }+3.3 \mathrm{~mm})\end{array}$ & - & $\mathrm{R}$ \\
\hline $\begin{array}{l}\text { (Powers et al. } \\
\text { 1994) [32] }\end{array}$ & 146 & 52 & NG & TMl & Fixed & $18-51 \mathrm{M}$ & $\mathrm{BF}(+2$ to $9 \mathrm{~mm})$ & - & $\mathrm{R}$ \\
\hline $\begin{array}{l}\text { (Adell et al. } \\
\text { 1981) [58] }\end{array}$ & 410 & 53 & 2768 & NG & $\begin{array}{l}\text { Removable } \\
\text { bridges }\end{array}$ & $5-9 Y$ & $\mathrm{BR}(+)$ & - & $\mathrm{R}$ \\
\hline $\begin{array}{l}\text { (Mericske- } \\
\text { Stern et al. } \\
\text { 2002) [35] }\end{array}$ & 41 & 61.2 & $4-6$ & Maxillary & $\begin{array}{l}\text { Removable } \\
\text { overdentures }\end{array}$ & $4.1 \mathrm{Y}^{\mathrm{a}}$ & $\mathrm{BD}(+)$ & $\begin{array}{l}\text { Associated with } \\
\text { radiographically } \\
\text { visible decrease of } \\
\text { the crestal bone. }\end{array}$ & $P$ \\
\hline $\begin{array}{l}\text { (Kwakman } \\
\text { et al. 1997) } \\
\text { [31] }\end{array}$ & 36 & 60 & NG & TMl & $\begin{array}{l}\text { Denture with } \\
\text { cantilever } \\
\text { extension }\end{array}$ & $2.3 Y^{a}$ & $\mathrm{BF}(+)$ & - & $\mathrm{R}$ \\
\hline $\begin{array}{l}\text { (Sennerby } \\
\text { et al. 1988) } \\
\text { [72] }\end{array}$ & 41 & 51.3 & NG & Symphyseal & Oerdenture & $7.1 Y^{\mathrm{a}}$ & $\mathrm{BR}(-)$ & Implant bony area vs CD & $\mathrm{R}$ \\
\hline $\begin{array}{l}\text { (Friberg et al. } \\
\text { 2000) [20] }\end{array}$ & 49 & 63 & 247 & NG & $\begin{array}{l}\text { Fixed } \\
\text { prosthesis }\end{array}$ & $8 Y^{a}$ & $\mathrm{BF}(+)$ & $\begin{array}{l}\text { At two most distal } \\
\text { implants }\end{array}$ & $\mathrm{R}$ \\
\hline $\begin{array}{l}\text { (Adell et al. } \\
\text { 1986) [19] }\end{array}$ & 16 & 53 & 95 & Maxillomandibular & $\begin{array}{l}\text { Removable } \\
\text { bridge }\end{array}$ & $3 Y^{a}$ & $\mathrm{BR}(+)$ & $\begin{array}{l}\text { Indicating a successive } \\
\text { load-related remodeling }\end{array}$ & $P$ \\
\hline $\begin{array}{l}\text { (Kordatzis } \\
\text { et al. 2003) } \\
\text { [74] }\end{array}$ & 150 & NG & 300 & Symphyseal & $\begin{array}{l}\text { Bar } \\
\text { overdenture }\end{array}$ & $5 Y^{a}$ & $\operatorname{BR}(-1 \mathrm{~mm})^{\mathrm{a}}$ & $\begin{array}{l}\text { Less bone atrophy with } \\
\text { OD vs CD. }\end{array}$ & $\mathrm{R}$ \\
\hline $\begin{array}{l}\text { (Woven \& } \\
\text { Gotfredsen } \\
\text { 1998) [78] }\end{array}$ & 22 & 65 & NG & Symphyseal & Overdentures & $5 Y^{a}$ & $\begin{array}{l}\mathrm{BF}(+) \\
\mathrm{BR}(-)\end{array}$ & $\begin{array}{l}\text { Function related BF vs } \\
\text { physiologic age-related BR }\end{array}$ & $P$ \\
\hline $\begin{array}{l}\text { (Wright et al. } \\
\text { 2002) [73] }\end{array}$ & 44 & $\begin{array}{l}53 \mathrm{Y}, \text { for } \\
\text { overdenture } \\
\text { and } 64 \mathrm{Y} \text { for the } \\
\text { fixed prosthesis }\end{array}$ & NG & NG & $\begin{array}{l}\text { Overdentures } \\
\text { and fixed } \\
\text { prostheses }\end{array}$ & $7.5 Y^{\mathrm{a}}$ & $\begin{array}{l}\mathrm{BR}(-0.5 \mathrm{~mm})^{\mathrm{a}} \\
\mathrm{BF}(+0.5 \mathrm{~mm})^{\mathrm{a}}\end{array}$ & $\mathrm{OD}$ and FD, respectively & $\mathrm{R}$ \\
\hline $\begin{array}{l}\text { (Shaarawy \& } \\
\text { Aboelross } \\
\text { 2013) [92] }\end{array}$ & 14 & 58 & $14+28$ & $\begin{array}{l}\text { Symphyseal and } \\
2 \text { in the first } \\
\text { molar area }\end{array}$ & Overdenture & $1 Y$ & $\mathrm{BD}(+)$ & $\begin{array}{l}\text { Incisal reduction of } \mathrm{BD} \\
\text { followed by gradual } \\
\text { increase in } \mathrm{BD}\end{array}$ & $P$ \\
\hline $\begin{array}{l}\text { (Taylor 1989) } \\
\text { [21] }\end{array}$ & 1 & $\begin{array}{l}50 \mathrm{Y} \\
\text { (not a mean) }\end{array}$ & 5 & NG & Fixed & $32 \mathrm{M}$ & VBH (3 mm) & - & $C R$ \\
\hline $\begin{array}{l}\text { (Oikarinen \& } \\
\text { Siirila 1992) } \\
\text { [60] }\end{array}$ & 1 & $41 Y$ & 6 & NG & Fixed & $8 Y^{a}$ & $\mathrm{VBH}(+)$ & $\begin{array}{l}\text { Nearly the doubled new } \\
\text { BF }\end{array}$ & $C R$ \\
\hline $\begin{array}{l}\text { (Betts et al. } \\
\text { 1993) [18] }\end{array}$ & 19 & NG & NG & TMl & Fixed & $53 \mathrm{M}$ & $\mathrm{VBH}(+1.8 \mathrm{~mm})^{\mathrm{a}}$ & $\begin{array}{l}\text { In the saddle area and the } \\
\text { most distal screw }\end{array}$ & $\mathrm{R}$ \\
\hline $\begin{array}{l}\text { (Dhima et al. } \\
\text { 2013) [33] }\end{array}$ & 81 & NG & NG & NG & Fixed & $9^{a}$ & $\mathrm{BF}(+0.94 \mathrm{~mm})^{\mathrm{a}}$ & - & $\mathrm{R}$ \\
\hline $\begin{array}{l}\text { (Mosnegutu } \\
\text { et al. 2015) } \\
{[81]}\end{array}$ & 82 & NG & NG & NG & Overdenture & $10.5 Y^{a}$ & $\mathrm{BR}( \pm)$ & $\begin{array}{l}\text { No relevant posterior bone } \\
\text { atrophy after loading }\end{array}$ & $P$ \\
\hline $\begin{array}{l}\text { (Cooper et al. } \\
\text { 2008) [79] }\end{array}$ & 59 & NG & 118 & Parasymphyseal & Overdenture & $60 M$ & $\mathrm{BF}(+)$ & - & $P$ \\
\hline
\end{tabular}

${ }^{\text {aAverage }}$

$N G$ not given, $T M I$ transmandibular implant, $Y$ year, $M$ month, $B F$ bone formation, $V B H$ vertical bone height, $B R$ bone radiopacity, $B D$ bone density, $B R$ bone resorption, $C D$ complete denture, $O D$ overdenture, $F D$ fixed denture, $R$ retrospective, $P$ prospective, $C R$ case report, $(+)$ increase, $(-)$ decrease, $( \pm)$ neutral

of follow-up [34]. Even with questionable histological bony condition, as in the maxilla with sinus lifting, favorable bone density is noticed [35, 36]. Follow-up for more than 3 years for 44 installed fixtures revealed a consistent bone formation and elevation of lining sinus mucosa without bone graft. [37] This goes with the conclusion of Lundgren et al. [38] as the replaceable bone window allows bone formation with the implant after sinus lift. 
Bone changes were reported after implant placement in three phases: healing, remodeling, and equilibrium. The remodeling phase is launched confronting the altered pattern of force transmission to the bone tissue. To withstand the applied functional load, continuous remodeling is conducted to reach a "steady state." Mechanical stimulus is the primary bone modifier influenced by other in situ variables as hormonal, metabolic, genetic factors [39].

Clinically, as affordable as the strain, bone regeneration is configured, whereas the over-stimulation leads to adverse effects [40]. The bone around unloaded implants showed a low mineral density index. [41] The process of inducing more dense bone depends mainly on the loading protocol conducted [42]. The peri-implant bone around progressively loaded implants illustrated minimal crestal bone loss than the bone around implants placed conventionally, and the later cited extended increase in peri-implant bone density by time [10]. Based on radiological assessment, Barone et al. [43] stated statistical significant dense bone around immediate rather than unloaded oral implants.

Histochemically, the mechanical effect controls bone formation and mass modification with a percentage about $40 \%$ comparing to other growth-related factors as hormonal or cytokine deliver about $10 \%$ of the postnatal changes in bone strength and mass. Thereby, mineralization and tissue reformation by osteoblasts are co-related to the local mechanical environment [44]. The blood supply and nutrition are mandatory as osteoblast acting on the osteoid bone formation [45]. Bone tissue that experienced physiologic load is liable for osteogenic deformation [46]. Thus, strain must be in the physiologic bone limit (500-3000 $\mu$ strain) according to the elasticity modulus, while overstrain ( $>5000 \mu$ strain) precipitates fibrogenesis $[44,47]$.

\section{Variations of bone resorption and preserving with different restorations}

Considering physiologic changes, the annual alveolar bone resorption is approximately fourfold more in mandible comparing to the maxilla [48]. A longitudinal monitoring of edentulous complete denture wearers admitted continuous reduction of the residual alveolar ridge throughout the study. The anterior part of the mandible showed the higher average of reduction compared to the estimated rate of the maxilla [49]. The variation between the jaws in alveolar bone reduction increased gradually during the first years of denture wearing. This evidenced the unfavorable response of the mandible to various functional stresses transmitted through the denture to the limited and diminished bearing area of the mandibular alveolar bone comparing to the maxilla [50].
Many procedures are used to recover denture foundation, but the majority is considered sophisticated techniques [51-53]. Observations tried to notify bone modifications with different types of implant-assisted restoration $[23,40,54]$. The clinical and radiographic investigations, detection of the altered mineral levels, or bone density within the bone may give a valuable data for the bony state around loaded implants [55-57]. In a prospective study, Adell et al. [19] noticed a reduction of probing depth around implants, resembling approximately that surround natural dentition which indicates active positive bone repair. A further sign of bone preserving is the radiopacity close to the fixture due to increasing in density [58]. Such radiopacity affirmed to increased bone volume and/or increased mineral content. Maxillary implants reflected more bone density rather than mandibular and distal cantilevered implants due to the stresses which may produce more unfavorable bone restoring condition. After 10 years of implant placement, a significant increase in peri-implant bone density was noted in a clinical study for 18 patients [59]. In two separate clinical reports, Taylor [21] reported patient's complain with cantilevered part after 32 months of loading. He elaborated that with mandibular growing for about $3 \mathrm{~mm}$. In the other case report by Oikarinen and Silrila [60], they mentioned new boney layer formation. Naert et al. [61] agreed with the role of the implant in residual ridge preservation even if there is no bone formation recorded.

\section{Destructive and preservative role of implant overdenture}

Occlusal load and different forces induced on the implant overdenture restoration, with the diminished supportive area, might be the main predisposing factor for bone resorption [62]. According to finite element analysis study, the available bearing area in case of complete denture is $4608.7 \mathrm{~mm}^{2}$ comparing to $2833.4 \mathrm{~mm}^{2}$ for the implant overdenture posteriorly which leads to an even pressure at the usage of complete denture comparing to higher load concentration on the posterior area available with overdenture [63]. This agreed with other study comparing hydrostatic pressure under the conventional versus implant overdenture which conceded the evenness of load distribution over the wide area of residual ridge, approximately $1926 \mathrm{~mm}^{2}$, and the volume average hydrostatic pressure at $10.670 .8 \mathrm{kPa}$, in case of complete denture. While the tissue-bearing area reduced to $71 \%$ with two implants and to $60.5 \%$ for four implant-assisted overdenture, the corresponding hydrostatic pressure was 14.370 .9 and $13.370 .9 \mathrm{kPa}$, respectively. The peak of posterior stresses was recorded with the two implant-assisted overdentures [64]. In a clinical retrospective study for 10 years, there was a significant difference in posterior ridge resorption with 
overdenture assisted with two and/or four implants. This was interpreted as the improved oral function and increased bite force may lead to more force concentration which does not exist in floated conventional denture [65]. Due to the anchorage of the denture anteriorly in the symphyseal area, the axial direction of force and the free movement posteriorly may exert more resorption in comparing to preserved bone close to implant anteriorly $[66,67]$. On the other hand, the best selection for supra-structure attachment with implant overdenture and the pre-intervention planning may reduce implant/ridge load by distributing forces in an even manner to act as the norm of implantsupported fixed dentures [68, 69]. Additional investigation elected the symphyseal implant overdenture as a good treatment modality without overestimation for posterior bone loss [70].

Despite age-related [71], local and/or systemic factors causing prolonged ridge resorption [9], authors reported the probability of preservative effect and overhaul to maintain the residual alveolar ridge with different restoration [70, 71]. In the previous study, bone formation was noticed with the distal implant in severely resorbed atrophied mandibular ridge [20]. Sennerby et al. [72] concluded that the treatment with tissue-integrated prostheses seems to reduce bone resorption in the mandible, probably owing to adequate favorable load to stimulate bone preservation. Patients rehabilitated with implant-stabilized mandibular overdenture demonstrated the preservation of posterior mandibular residual ridge from resorption by annual range +0.009 to $-0.048 \mathrm{~mm}$, while patients with mandibular implant fixed cantilever prostheses elaborated bone apposition, in the same area, with $1.6 \%$ annually [73]. Additionally, Kordatzis et al. [74] concluded 1-mm annual reduction in bone loss at using implant overdenture comparing to the conventional denture. Davis et al. [17] noticed the liability of the severely resorbed mandible for regeneration. After more than 4 years of function, anterior implant regenerated bone in the mental foramen area created a mandibular canal that previously was unseen. Even with loaded comparing to non-loaded implant in the same patient, the loaded implant demonstrated more bone preservation [75]. Within the 4-year study of implantsupported overdenture, preservation and gaining of more bones were preserved. Clinical examination revealed $0.8 \mathrm{~mm}$ mean annual marginal bone loss during the first year and $0.1 \mathrm{~mm}$ in the following years [76]. Also, the bony area close to the implants has advantaged reduction in bone resorption. The reduced resorption rate with implant-supported overdenture is significantly proportional to the distance from the distal implant which contributes to protecting the posterior residual ridge from excessive loading $[74,77]$. In a retrospective 5-year study, 22 patients with bar retained and freestanding implant overdenture patients demonstrated a significant preservation of bone surrounding implant. The increased function after prosthetic rehabilitation reflected load-related bone deposition which minimized the physiologic age-related mandibular bone mineral content loss regardless the attachment system [78]. A non-significant bone gain was recorded with 59 patients after wearing overdenture for 60 months [79]. Another clinical investigation, extended for 8 years, proved the usage of bar-assisted overdenture in the treatment of severely resorbed alveolar ridge represented preservation and minimal rate bone resorption regardless the design of bar [80]. The same conclusion was announced by Mosnegutu et al. [81] after 10 years of follow-up for some cases. Transmission of load axially toward implant followed by posterior load on the ridge initiated a negative consequence on the posterior bone and preservative positive alveolar bone response around osseointegrated implants [82]. Development of high strain in the alveolar region is inevitable causing crestal bone resorption [83, 84]. Strain levels in peri-implant bone are reduced as the insertion depth of the implant increased [85]. The chance of bone preserving is high in normal range of load and in the absence of abnormal overload conditions [69].

As most of the previous studies declared the favorable bone preservation of the residual alveolar ridge anteriorly around implants, biomechanically, and according to finite element analysis, bone modifying shows variations depending on the cancellous or cortical nature. Bone density is enhanced gradually from the third month to the end of the first year of loading coming stable after 30 months. Whoever, bone adaptive activities expose more impact on cancellous areas more than other parts [86]. Favorable bone remodeling may occur close to implants in partially edentulous patient because of the chance to be surrounded by alveolar rather than basal bone [26]. Thus, the cortical bone reveals more force concentration and liability to resorb rather than the cancellous bone showing more liability to accommodate with the induced forces [87, 88]. According to Chou et al. [89], the topography of the fixture reported alternative responses to load promotes a variation of bone remodeling. Due to the diminished bone surrounding, mini-implants revealed less bone adaptive capacity [90]. The threaded fixture represented bone apposition at the tip of threads and subsequent resorption at the bottoms. The non-threaded smooth implant revealed increasing in bone density at the apical section with a connection of high-density region to the cortical bone. According to Li et al. [91], positive density was illustrated deeper to the implant surface which may be due to the mechanical stimulus on the favorable cancellous bone. 


\section{Conclusions}

Within the limitation of this review and based on previous studies, implant restoration has a noticeable residual alveolar ridge preservation which varies from reducing rate of physiologic resorption to bone apposition. However, the extension of this preservation from the implant to surrounding bony area, horizontally and vertically, is unknown. So, further studies are needed to elaborate the extension of preservation and the influencing factors.

\section{Competing interests}

Ahmed Khalifa Khalifa, Masahiro Wada, Kazunori Ikebe, and Yoshinobu Maeda declare that they have no competing interests.

\section{Author's contribution}

AK drafted the manuscript. MW and IK helped to draft the manuscript. YM conceived of the study, participated in its design and coordination, and helped to draft the manuscript. All authors read and approved the final manuscript.

\section{Author details}

${ }^{1}$ Department of Prosthodontics, Faculty of Dentistry, Mansoura University, 68 ElGomhoria Street, ElMansoura 35516, Egypt. ²Department of Prosthodontics, Gerodontology and Oral Rehabilitation, Osaka University Graduate School of Dentistry, 1-8 YamadaokaSuita, Osaka 565-0871, Japan.

Received: 21 May 2016 Accepted: 16 November 2016

Published online: 23 November 2016

\section{References}

1. Petersen PE, Bourgeois D, Ogawa H, Estupinan-Day S, Ndiaye C. The global burden of oral diseases and risks to oral health. Bull World Health Organ. 2005;83(9):661-9.

2. Nowjack-Raymer RE, Sheiham A. Association of edentulism and diet and Nutrition in US adults. J Dent Res. 2003:82(2):123-6.

3. Araújo $M G$, Lindhe J. Dimensional ridge alterations following tooth extraction. An experimental study in the dog. J Clin Periodontol. 2005;32(2):212-8.

4. Atwood DA. Bone loss of edentulous alveolar ridges. J Periodontol. 1979:50(4 Spec No):11-21.

5. Famili P, Cauley J, Suzuki JB WR. Longitudinal study of periodontal disease and edentulism with rates of bone loss in older women. J Periodontol. 2005;76(1):11-5.

6. Heydecke G, Locker D, Awad MA, Lund JP, Feine JS. Oral and general health-related quality of life with conventional and implant dentures. Community Dent Oral Epidemiol. 2003;31(3):161-8.

7. van Kampen FMC, van der Bilt A, Cune MS, Fontijn-Tekamp FA, Bosman F. Masticatory function with implant-supported overdentures. J Dent Res. 2004;83(9):708-11.

8. Cooper LF. Biologic determinants of bone formation for osseointegration: clues for future clinical improvements. J Prosthet Dent. 1998:80(4):439-49.

9. Carlsson GE. Responses of jawbone to pressure. Gerodontology. 2004; 21(2):65-70.

10. Appleton RS, Nummikoski PV, Pigno MA, Cronin RJ, Chung KH. A radiographic assessment of progressive loading on bone around single osseointegrated implants in the posterior maxilla. Clin Oral Implants Res. 2005;16(2):161-7.

11. Kivovics P, Jáhn M, Borbély J, Márton K. Frequency and location of traumatic ulcerations following placement of complete dentures. Int J Prosthodont. 2007;20(4):397-401.

12. Kreisler M, Behneke $\mathrm{N}$, Behneke $\mathrm{A}$, d'Hoedt $\mathrm{B}$. Residual ridge resorption in the edentulous maxilla in patients with implant-supported mandibular overdentures: an 8-year retrospective study. Int J Prosthodont. 2003; 16(3):295-300.

13. Närhi TO, Ettinger RL, Lam EW. Radiographic findings, ridge resorption, and subjective complaints of complete denture patients. Int J Prosthodont. 1997;10(2):183-9.

14. Pjetursson BE, Karoussis I, Bürgin W, Brägger U, Lang NP. Patients' satisfaction following implant therapy. A 10-year prospective cohort study. Clin Oral Implants Res. 2005;16(2):185-93.
15. Klemetti E, Kolmakow S. Morphology of the mandibular cortex on panoramic radiographs as an indicator of bone quality. Dentomaxillofacial Radiol. 1997;26(1):22-5.

16. Ortman LF, McHenry K, Hausmann E. Relationship between alveolar bone measured by ${ }^{125}$ absorptiometry with analysis of standardized radiographs: 2. Bjorn technique. J Periodontol. 1982;53(5):311-4.

17. Davis WH, Lam PS, Marshall MW, Dorchester W, Hochwald DA, Kaminishi RM. Using restorations borne totally by anterior implants to preserve the edentulous mandible. J Am Dent Assoc. 1999;130(8):1183-9.

18. Betts NJ, Barber HD, Powers MP, Wu L, Hennig T, Fonseca RJ. Osseous changes following placement of the transmandibular implant system in edentulous mandibles. Implant Dent. 1993;2(1):11-7.

19. Adell R, Lekholm U, Rockler B, Branemark PI, Lindhe J, Eriksson B, et al. Marginal tissue reactions at osseointegrated titanium fixtures. (I). A 3-year longitudinal prospective study. Int J Oral Maxillofac Surg. 1986;15(1):39-52

20. Friberg B, Gröndahl K, Lekholm U, Brånemark PI. Long-term follow-up of severely atrophic edentulous mandibles reconstructed with short Brånemark implants. Clin Implant Dent Relat Res. 2000;2(4):184-9.

21. Taylor TD. Osteogenesis of the mandible associated with implant reconstruction: a patient report. Int J Oral Maxillofac Implants. 1989;4(3):227-31.

22. Hassler CR, Rybicki EF, Cummings KD, Clark LC. Quantification of bone stresses during remodeling. J Biomech. 1980;13(2):185-90.

23. Akca K, Iplikcioglu H. One-year follow-up of an implant with early radiographic signs of loss of osseointegration: case report. Clin Implant Dent Relat Res. 2002;4(1):43-6.

24. Brägger U, Hugel-pisoni C, Bürgin W, Buser D, Lang NP. Correlations between radiographic, clinical and mobility parameters after loading of oral implants with fixed partial dentures. A 2 years longitudinal study.pdf. Clin Oral Implants Res. 1996;7(3):230-9.

25. Carlsson GE. Implant and root supported overdentures-a literature review and some data on bone loss in edentulous jaws. J Adv Prosthodont. 2014:6(4):245-52

26. Lekholm U. Osseointegrated implants in the treatment of partially edentulous jaws: a prospective 5-year multicenter study. Int J Oral Maxillofac Implants. 1994;9:627-35.

27. Roberts WE, Helm FR, Marshall KJ, Gongloff RK. Rigid endosseous implants for orthodontic and orthopedic anchorage. Angle Orthod. 1989;59(4):247-56.

28. Roberts WE, Smith RK, Zilberman Y, Mozsary PG, Smith RS. Osseous adaptation to continuous loading of rigid endosseous implants. Am J Orthod. 1984;86(2):95-111.

29. Wyatt CCLL. The effect of prosthodontic treatment on alveolar bone loss: a review of the literature. J Prosthet Dent. 1998;80(3):362-6.

30. Ichikawa T, Miyamoto M, Horisaka Y, Horiuchi M. Radiographic analysis of a two-piece apatite implant: part II. Preliminary report of 2-year observation. Int J Oral Maxillofac Implants. 1997:9(2):214-22.

31. Kwakman JM, Van Waas MAJ, Hagens M, Voorsmit RACA. Bone level changes in patients with transmandibular implants. J Oral Maxillofac Surg. 1997;55:15-8.

32. Powers MP, Bosker $\mathrm{H}$, Van Pelt $\mathrm{H}$, Dunbar N. The transmandibular implant: from progressive bone loss to controlled bone growth. J Oral Maxillofac Surg. 1994:52(9):904-10

33. Dhima M, Balshi T, Wolfinger $G$, Petropoulos VC, Balshi S. A retrospective analysis of mandibular bone height changes associated with 81 screwretained implant-supported prostheses with distal cantilevers: a long-term follow-up analysis. Int J Oral Maxillofac Implants. 2013;28(3):854-9.

34. Saulacic N, Abboud M, Pohl Y. Clinical and radiographic outcome of dental implants supporting fixed prostheses: the relevance of cortical bone formation. Implant Dent. 2012;21(4):323-9.

35. Mericske-Stern R, Oetterli M, Kiener P, Mericske E. A follow-up study of maxillary implants supporting an overdenture: clinical and radiographic results. Int J Oral Maxillofac Implants. 2002;17(5):678-86.

36. Block MS, Kent JN, Kallukaran U, Thunthy K, Weinberg R. Maintenance after sinus 5 to 10 years grafting. J Oral Maxillofac Surg. 1998;56(6):706-14.

37. Thor A, Sennerby L, Hirsch JM, Rasmusson L. Bone formation at the maxillary sinus floor following simultaneous elevation of the mucosal lining and implant installation without graft material: an evaluation of 20 patients treated with 44 Astra Tech implants. J Oral Maxillofac Surg. 2007;65 Suppl 7:64-72.

38. Lundgren S, Anderson S, Gualini F, Sennerby L. Bone reformation with sinus membrane elevation: a new surgical technique for maxillary sinus floor augmentation. Clin Implant Dent Relat Res. 2004;6(3):165-73.

39. Cowin SC. Bone stress adaptation models. J Biomech Eng. 1993;115(4B):528. 
40. Byrne G. Fundamentals of implant dentistry. New Jersey: Wiley; 2014. 264 p.

41. Traini T, Degidi M, lezzi G, Artese L, Piattelli A. Comparative evaluation of the peri-implant bone tissue mineral density around unloaded titanium dental implants. J Dent. 2007;35(1):84-92.

42. Hoshaw SJ, Brunski JB, Cochran GVB. Mechanical loading of Brånemark implants affects interfacial bone modeling and remodeling. Int J Oral Maxillofac Implants. 1994;9:345-60.

43. Barone A, Covani U, Cornelini R, Gherlone E. Radiographic bone density around immediately loaded oral implants: a case series. Clin Oral Implants Res. 2003;14(5):610-5.

44. Joos U, Wiesmann HP, Szuwart T, Meyer U. Mineralization at the interface of implants. Int J Oral Maxillofac Surg. 2006;35(9):783-90.

45. Brunski JB. In vivo bone response to biomechanical loading at the bone/ dental-implant interface. Adv Dent Res. 1999;13(1):99-119.

46. Frost HM. The Utah paradigm of skeletal physiology: an overview of its insights for bone, cartilage and collagenous tissue organs. J Bone Miner Metab. 2000;18(6):305-16.

47. Jones D, Leivseth G, Tenbosch J. Mechano-reception in osteoblast-like cells. Biochem Cell Biol. NRC Research Press Ottawa. Canada. 1995;73(7-8):525-34.

48. Atwood DA, Coy WA. Clinical, cephalometric, and densitometric study of reduction of residual ridges. J Prosthet Dent. 1971;26(3):280-95.

49. Tallgren A. The continuing reduction of the residual alveolar ridges in complete denture wearers: a mixed-longitudinal study covering 25 years. J Prosthet Dent. 1972;27(2):120-32.

50. Carlsson GE. Clinical morbidity and sequelae of treatment with complete dentures. J Prosthet Dent. 1998;79(1):17-23.

51. Bhola M, Newell DH, Hancock EB. Acellular dermal allograft for vestibuloplasty - an alternative to autogenous soft tissue grafts in preprosthetic surgical procedures: a clinical report. J Prosthodont. 2003;12(2):133-7.

52. Cillo JE, Finn R. Reconstruction of the shallow vestibule edentulous mandible with simultaneous split thickness skin graft vestibuloplasty and mandibular endosseous implants for implant-supported overdentures. J Oral Maxillofac Surg. 2009;67(2):381-6.

53. Metin M, Dolanmaz D, Alkan A. Evaluation of autogenous grafts used in vestibuloplasty. J Int Med Res. 2003;31(4):335-9.

54. Block MS, Kent JN, Finger IM. Use of the integral implant for overdenture stabilization. Int J Oral Maxillofac Implants. 1990;5(2):140-7.

55. Norton MR, Gamble C. Bone classification: an objective scale of bone density using the computerized tomography scan. Clin Oral Implants Res. 2001;12(1):79-84.

56. de Oliveira RCG, Leles CR, Normanha LM, Lindh C, Ribeiro-Rotta RF. Assessments of trabecular bone density at implant sites on CT images. Oral Surg Oral Med Oral Pathol Oral Radiol Endod. 2008;105(2):231-8.

57. Amorim MAL, Takayama L, Jorgetti V, Pereira RMR. Comparative study of axial and femoral bone mineral density and parameters of mandibular bone quality in patients receiving dental implants. Osteoporos Int. 2007;18(5):703-9.

58. Adell R, Lekholm U, Rockler B, Brånemark P-I. A 15-year study of osseointegrated implants in the treatment of the edentulous jaw. Int J Oral Surg. 1981;10(6):387-416

59. Jacobs R, Pittayapat P, Van Steenberghe D, De Mars G, Gijbels F, Van Der Donck A, et al. A split-mouth comparative study up to 16 years of two screwshaped titanium implant systems. J Clin Periodontol. 2010;37(12):1119-27.

60. Oikarinen VJ, Sirila HS. Reparative bone growth in an extremely atrophied edentulous mandible stimulated by an osseointegrated implant-supported fixed prosthesis: a case report. Int J Oral Maxillofac Implants. 1992;7(4):541-4.

61. Naert I, Koutsikakis G, Duyck J, Quirynen M, Jacobs R, van Steenberghe D. Biologic outcome of implant-supported restorations in the treatment of partial edentulism. Part 1: a longitudinal clinical evaluation. Clin Oral Implants Res. 2002;13(4):381-9.

62. Klemetti E. A review of residual ridge resorption and bone density J Prosthet Dent. 1996;75(5):512-4.

63. Ahmad R, Chen J, Abu-Hassan MI, Li Q, Swain MV. Investigation of mucosainduced residual ridge resorption under implant-retained overdentures and complete dentures in the mandible. Int J Oral Maxillofac Implants. 2015;30(3):657-66.

64. Chen J, Ahmad R, Suenaga H, Li W, Swain M, Li Q. A comparative study on complete and implant retained denture treatments: a biomechanics perspective. J Biomech. 2015;48(3):512-9.

65. de Jong MHM, Wright PS, Meijer HJA, Tymstra N. Posterior mandibular residual ridge resorption in patients with overdentures supported by two or four endosseous implants in a 10-year prospective comparative study. Int J Oral Maxillofac Implants. 2010;25(6):1168-74.

66. Jacobs R, Schotte A, van Steenberghe D, Quirynen M, Naert I. Posterior jaw bone resorption in osseointegrated implant-supported overdentures. Clin Oral Implants Res. 1992;3(2):63-70.

67. Blum IR, Fraser MCJ. A clinical investigation of the morphological changes in the posterior mandible when implant-retained overdentures are used. Clin Oral Implants Res. 2004;15(6):700-8.

68. Mazaro JVQ, Filho HG, Vedovatto E, Pellizzer EP, Rezende MCRA, Zavanelli AC. Evaluation of stress patterns produced by implant-retained overdentures and implant-retained fixed partial denture. J Craniofac Surg. 2011;22(6):2153-7.

69. Arat Bilhan S, Baykasoglu C, Bilhan H, Kutay O, Mugan A. Effect of attachment types and number of implants supporting mandibular overdentures on stress distribution: a computed tomography-based 3D finite element analysis. J Biomech Elsevier. 2015;48(1):130-7.

70. Raedel M, Lazarek-Scholz K, Marr B, Boening KW, Walter MH. Posterior alveolar ridge resorption in bar-retained mandibular overdentures: 10-year results of a prospective clinical trial. Clin Oral Implants Res. 2015;26(12):1397-401.

71. Harrison A. Alveolar bone resorption in two edentulous populations. J Dent. 1972:1 (2):77-82.

72. Sennerby L, Carlsson G, Bergman B, Warfvinge J. Mandibular bone resorption in patients treated with tissue-integrated prostheses and in complete-denture wearers. Acta Odontol Scand. 1988;46(3):135-40.

73. Wright PS, Glantz P-O, Randow K, Watson RM. The effects of fixed and removable implant-stabilised prostheses on posterior mandibular residual ridge resorption. Clin Oral Implants Res. 2002;13(2):169-74.

74. Kordatzis K, Wright PS, Meijer HJ. Posterior mandibular residual ridge resorption in patients with conventional dentures and implant overdentures. Int J Oral Maxillofac Implants. 2003;18(3):447-52.

75. Naert I, Gizani S, van Steenberghe D. Bone behavior around sleeping and non-sleeping implants retaining a mandibular hinging overdenture. Clin Oral Implants Res. 1999;10(2):149-54.

76. Quirynen M, Naert I, Steenberghe D, Teerlinck J, Dekeyser C, Theuniers G. Periodontal aspects of osseointegrated fixtures supporting an overdenture. A 4-year retrospective study. J Clin Periodontol. 1999:18(10):719-28.

77. Kremer U, Schindler S, Enkling N, Worni A, Katsoulis J, Mericske-Stern R. Bone resorption in different parts of the mandible in patients restored with an implant overdenture. A retrospective radiographic analysis. Clin Oral Implants Res. 2016;27(3):267-72.

78. von Wowern N, Gotfredsen K. Implant-supported overdentures, a prevention of bone loss in edentulous mandibles? A 5-year follow-up study. Clin Oral Implants Res. 2001;12(1):19-25.

79. Cooper LF, Moriarty JD, Guckes AD, Klee LB, Smith RG, Almgren C, et al. Five-year prospective evaluation of mandibular overdentures retained by two microthreaded, TiOblast nonsplinted implants and retentive ball anchors. Int J Oral Maxillofac Implants. 2008;23(4):696-704.

80. Wright PS, Watson RM. Effect of prefabricated bar design with implantstabilized prostheses on ridge resorption: a clinical report. Int J Oral Maxillofac Implants. 1998;13(1):77-81.

81. Mosnegutu A, Wismeijer D, Geraets W. Implant-supported mandibular overdentures can minimize mandibular bone resorption in edentulous patients: results of a long-term radiologic evaluation. Int J Oral Maxillofac Implants. 2015;30(6):1378-86.

82. Naert IE, Hooghe M, Quirynen M, van Steenberghe D. The reliability of implant-retained hinging overdentures for the fully edentulous mandible. An up to 9-year longitudinal study. Clin Oral Invest. 1997;1(3): $119-24$

83. Liu J, Pan S, Dong J, Mo Z, Fan Y, Feng H. Influence of implant number on the biomechanical behaviour of mandibular implant-retained/ supported overdentures: a three-dimensional finite element analysis. J Dent. 2013;41(3):241-9.

84. Shigemitsu R, Yoda N, Ogawa T, Kawata T, Gunji Y, Yamakawa Y, et al. Biological-data-based finite-element stress analysis of mandibular bone with implant-supported overdenture. Comput Biol Med. 2014;54:44-52.

85. Chou HY, Müftü S, Bozkaya D. Combined effects of implant insertion depth and alveolar bone quality on periimplant bone strain induced by a widediameter, short implant and a narrow-diameter, long implant. J Prosthet Dent. 2010;104(5):293-300.

86. Lin D, Li Q, Li W, Duckmanton N, Swain M. Mandibular bone remodeling induced by dental implant. J Biomech. 2010;43(2):287-93. 
87. Huiskes R, Weinans H, Grootenboer HJ, Dalstra M, Fudala B, Slooff TJ. Adaptive bone-remodeling theory applied to prosthetic-design analysis. J Biomech. 1987;20(11-12):1135-50.

88. Murphy WM, Williams KR, Gregory MC. Stress in bone adjacent to dental implants. J Oral Rehabil. 1995;22(12):897-903.

89. Chou HY, Jagodnik JJ, Müftü S. Predictions of bone remodeling around dental implant systems. J Biomech. 2008;41(6):1365-73.

90. Chang S-H, Huang S-R, Huang S-F, Lin C-L. Mechanical response comparison in an implant overdenture retained by ball attachments on conventional regular and mini dental implants: a finite element analysis. Comput Methods Biomech Biomed Engin. 2015;5842(April):1-11.

91. Li J, Li H, Shi L, Fok ASL, Ucer C, Devlin H, et al. A mathematical model for simulating the bone remodeling process under mechanical stimulus. Dent Mater. 2007;23(9):1073-8.

92. Shaarawy MA, Aboelross EM. The effect of varying implant position in immediately loaded implant-supported mandibular overdentures. J Oral Implantol. 2013;39(3):345-54.

\section{Submit your manuscript to a SpringerOpen ${ }^{0}$ journal and benefit from:}

- Convenient online submission

- Rigorous peer review

- Immediate publication on acceptance

- Open access: articles freely available online

- High visibility within the field

- Retaining the copyright to your article

Submit your next manuscript at $>$ springeropen.com 